\title{
A STUDY OF PSYCHOLOGICAL SUPPORT FROM LOCAL RESIDENTS FOR HOSTING MEGA-SPORTING EVENTS: A CASE OF THE 2012 INDIANAPOLIS SUPER BOWL XLVI
}

\author{
SOONHWAN LEE AND BRIAN D. KROHN \\ IU School of Physical Education and Tourism Management, Indiana University-Purdue University, \\ Indianapolis, IN, USA
}

\begin{abstract}
The purpose of the current study was to assess local residents' psychological support prior to hosting a mega-sporting event and to report preliminary results as to which factors of support affect local residents' attitudes toward hosting future mega-sporting events, using the case of the 2012 Super Bowl in Indianapolis. This study provides a theoretical model to examine local residents' psychological support factors using structural equation modeling, which helps the understanding of local residents in the process of supporting the hosting of mega-sporting events in the future. The results of this study indicate that the perceptions of positive outcomes from the event have the strongest relationship to feelings toward hosting future events. Therefore, governing bodies of the host community and the event should rely most heavily on the positive outcomes. While the negative factors were not as strongly related, they were still significant indicators of feelings toward future events. The part of the plans pertaining to growing community support should include ways that the negative impacts might be mitigated.
\end{abstract}

Key words: Psychological impacts; Community support; Positive externalities; Negative externalities; Mega-sporting events

\section{Introduction}

The Super Bowl is one of the biggest 1-day competitive televised sporting events in the world. According to Nielsen (2010), more than 106 million people watched the 2010 Super Bowl XLIV on television in the US, which made it the most watched television program in history. Owing to heavy public attention on mega-sporting events, civic boosters and community residents often discuss hosting a Super Bowl or other mega-sporting events like the Olympic Games and the FIFA Soccer World Cup. Given this public attention on a host city, it is important to address the impacts hosting mega-sporting events has upon the local residents.

Address correspondence to Brian D. Krohn, Ph.D., Assistant Professor, Department of Tourism, Conventions and Event Management, School of Physical Education and Tourism Management, Indiana University-Purdue University Indianapolis (IUPUI), 901 West New York Street, Office 258A, Indianapolis, IN 46202, USA. Tel: +1-317-274-7615; Fax: +1-317-278-2041; E-mail: bkrohn@iupui.edu 
One such impact that is often discussed is that of economic impact. However, some of this discussion focuses on controversial issues involved with many applications of economic impact methodology including inaccurate estimating methods, legitimizing political positions, and mischievous procedures of economic modeling (Berrett, 2001; Cornelissen, 2004; Crompton, 2004; Desbordes, 2007; Gratton, Shibli, \& Coleman, 2006). Many economic impact studies focus on hosting mega-sporting events and are commissioned by political organizations that seek to support the planning and development of the event. These studies favor results that support the anticipated outcomes of the organization. While these economic impact studies are often conducted to support political perspectives of the planning and development of mega-sporting events (Gursoy \& Kendall, 2006), relatively limited research has been carried out to discuss residents' psychological support.

While psychological impact is defined as perceived benefits (i.e., positive externalities) and/ or costs (i.e., negative externalities) after sporting events, psychological support is defined as local residents' psychological or financial willingness to host sporting events with expectation of benefits prior to hosting the events. Therefore, psychological support from local residents plays an important role in providing tangible and/or intangible justifications when planning for sustainability for developing mega-sporting events in the future. Not only does the success of sporting events depend heavily on the goodwill of the local residents but also the longevity of the positive impacts is likely to be determined by the level of local residents' support for the sporting event (Deccio \& Baloglu, 2002). Local residents' psychological support by implementing more democratic planning approach for hosting mega-sporting events, such as Toronto's bid for the 1996 Summer Olympic Games and Calgary Olympics, provided that community involvement and support may transform such event host experiences to become significant urban experiences for host and guests (Hiller, 1990).

Although many sporting event impact studies tend to focus on only economic impacts, noneconomic impacts like psychosocial perceptions should be considered as an important part of the total impacts for hosting sporting events (Bob \& Swart, 2009;
Crompton, 2004). Psychological impacts include increased awareness and visibility for the host community, enhanced image, and emotional and psychological benefits that residents perceive, whether or not they attend sporting events or are involved in host organizations (Bob \& Swart, 2009; Crompton, 2004; Turco, 1995). Mega-sporting events such as the Super Bowl, Olympics, FIFA Soccer World Cup, or Tour de France provide an opportunity for building community consciousness and social bonding. Hosting mega-sporting events is increasingly used as a part of strategies for developing a sense of community (Hall, 1992; Morgan, 1997). When a city hosts a sporting event, not only are direct participants affected but also a broad segment of the population becomes excited and identifies with the event. As Crompton (2004) suggests, a sporting event is an investment in emotional infrastructure and provides benefits to communities in addition to economic impacts. It is also suggested that conducting psychological impact studies would be an effective way to influence local residents positively and provide more legitimate underpinning for public support of hosting mega-sporting events (Gursoy \& Kendall, 2006). Hosting mega-sporting events require considerable investment of human, financial, and physical resources from host communities; thus, a lack of coordination and support from host city residents may cause problems in planning and preparing for hosting a sporting event (Haxton, 1999). Fredline and Faulkner (2001), Hiller (1990), and Gursoy and Kendall (2006) have suggested that there are several important reasons why it is necessary to conduct background research so that an understanding of psychological support from local residents can be gained. First, local residents are often asked to vote for increasing tax to financially support for constructing or renovating infrastructure and facilities. Second, local residents are critical in transforming a mega-event into an urban festival to provide a significant experience for themselves and event guests. Third, local residents' support and involvement are likely to increase the longevity of positive impacts on the local community. Fourth, understanding that local residents' support is related to residents' reaction to an event, efforts could be made to minimize negative impacts (Fredline \& Faulkner, 2001; Hiller, 1990; Gursoy \& Kendall, 2006). 
The purpose of this article is to build on the existing body of knowledge by further developing and testing a model to aid in the understanding of local residents' psychological support for hosting mega-sporting events. First, there will be a review of literature pertaining to psychological impacts, specifically positive and negative externalities. Second, a review of social exchange theory will guide the future development and refinement of a model presented by Lee, Shin, and Park (2009).

Next, the article will discuss the structural equation model used to identify and test components of psychological support and present the results from this analysis. Implications and suggestions for future directions targeted toward marketing and management of mega-sporting events are provided.

\section{Review of Related Literature}

\section{Positive Externalities}

Externalities are defined as economic or social effects, which are benefits or costs that occur from an economic activity that affects people other than those directly involved in a market transaction (Santo, 2010). Positive externalities are referred to as the benefits on third parties by hosting megasporting events (Leed \& Allemen, 2005). For example, mega-sporting events can generate positive outcomes and consequences for the hosting communities that include image and awareness enhancement, leisure resource development, positive economic impacts, and infrastructure development (Burns, Hatch, \& Mules, 1986; Crompton, 2004; Lee et al., 2009; Morgan, 1997; Preuss, 2005; Turco, 1995).

One positive externality that mega-sporting events generate is the significant amount of media exposure for the hosting communities before, during, and after their occurrence (Crompton, 2004). Favorable and concentrated publicity for hosting communities from national and international media is considered as one of the biggest benefits for hosting the sporting events. Since the spread of television during the late 1950s, hosting mega-sporting events has become one of the most effective ways to improve positive image and be shown as a successful community (Whitson \& Macintosh, 1996). Because sporting events may enhance the positive tourism image of an area, there is the potential for future economic benefit by attracting new visitors, resulting from this increased community visibility and image (Lee et al., 2009). The pervasive popularity of sporting events has convinced communities that hosting sporting events may be a useful vehicle to enhance their images. The enhanced image can have long-term positive effects on tourism and tourism investment (Preuss, 2005).

Hosting mega-sporting events, many times, provides an opportunity to develop or renovate leisure and recreational sport resources. For instance, a significant increase in physical activity participation using the renovated World Cup facilities was recorded as a result of the 2006 Soccer World Cup in Germany (Buss, 2007). For the 2010 World Cup, an estimated over $\$ 1$ billion was spent in building and renovating 10 stadiums, training of volunteers, multisport code festivals, and recreation events and grass roots development projects, which add to capacity and resource provisions that are earmarked for providing more opportunities and quality experiences in sport and recreation across the country (Wikipedia, 2010).

Hosting sporting events can also stimulate the growth of existing businesses and establishment of new ones. Constructing or renovating sport facilities fosters surrounding development because they are physically interwoven with components of local businesses. New sport facilities are likely to capture much of the spending that used to occur in nearby businesses like restaurants, bars, hotels, and merchandise stores (Seigfried \& Zimbalist, 2000). Visibility of the hosting community and the resulting prosperous image from appearing on national and international media may induce more opportunities to attract other future mega-sporting events, conventions, and businesses. These mega-sporting events may generate other business development opportunities for local businesses in supplying products and services and making export opportunities for some manufactured products, which also result in additional spending by nonresidents associated with the events (Lee et al., 2009).

There is evidence that mega-sporting events like the Super Bowl or Olympic Games have a beneficial effect on urban economies through direct economic impact. For example, Hotchkiss, Moore, and Zobay (2003) examined certain counties in Georgia for evidence of effects from hosting the 1996 
Summer Olympic Games. They found that employment rates rose by $17 \%$ more than they did in nonOlympic venue counties. J. M. Humphreys (1994) also examined the effect on Georgia in hosting the 1994 Super Bowl. He estimated that the economic impacts of hosting the Super Bowl were \$166 million in spending, \$56 million in additional earnings, and 2,736 jobs created. Another study, conducted by Blake (2005), analyzed the impact on gross domestic product (GDP) "with” and "without” the Olympics for the 2012 Olympics in London using a computable general equilibrium model (CGEM). The study found that positive economic impacts from the London Olympics will be distributed into expenditures on infrastructure enhancements. Between $11 \%$ and $12 \%$ of the effect on GDP is attributable to expenditure on infrastructure development for the UK and more specifically London (Blake, 2005). Impacts from mega-sporting events can be widely distributed through infrastructure development as the host city prepares for these events. While research has found evidence of direct economic impact, it is important to consider the residents' perceptions of impact when examining community support for hosting megasporting events.

There are some examples where events were considered a catalyst for urban restructuring and embodied general trends in urban development and planning (Baade \&Matheson, 2004). For example, the 1992 Barcelona Olympic Games were the best example of how hosting a mega-sporting event with public support can provide development of infrastructure for improved quality of life for local residents. This event provided an important incentive and target date to complete long-held visions to develop road and transportation system infrastructure, housing, office and commercial developments, and hotel facilities. The Olympic Games left a comprehensive physical legacy that provided the basis for Barcelona's subsequent economic regeneration (Carriere \& Demaziere, 2002).

A mega-sporting event increases the opportunity that a host community will use the event as a basis for wide-scale redevelopment as Beijing did for the 2008 Olympic Games (Broudehoux, 2007). Magdalinski and Nauright (2004) proposed that one of the most common and successful strategies for civic boosters to obtain public subsidies in developing infrastructure was hosting mega-sporting events.
Although hosting mega-sporting events is extremely costly for host sites, previous studies suggested that one of the most significant perceived benefits of sporting events by residents was lasting facilities created for the event and used by locals after the event (Crompton, 2004; Gratton, Dobson, \& Shibli, 2000; Goldman, \& Nakazawa, 1997; Preuss, 2005). Financial support from local residents for sporting events becomes greater if the locals perceive infrastructure development for sporting events as something that will improve the facilities that the locals can enjoy or that would increase the opportunities of sport activities for the communities (Noll \& Zimbalist, 1997; Steiner \& Thöni, 1999; Turco, 1995).

\section{Negative Externalities}

Although most civic and sport boosters likely focus only on the positive economic and psychosocial impacts, there have been several negative externalities, which are defined as the costs that are imposed on third parties by hosting sporting events. The negative externalities perceived by local residents in hosting mega-sporting events are well recognized by the previous studies (Crompton, 2004; Dwyer, Mellor, Mistilis, \& Mules, 2000; Getz, 1991; Haynes, 2001; Higham, 1999; J. M. Humphreys \& Plummer, 1995; Preuss \& Solberg, 2006; Rascher, 2002; Tosun, 2002). Roche (1994) also stated that mega-events were short-term events but had long-term consequences with negative aspects for the host cities in many cases. For example, hosting mega-sporting events is likely to cause some negative externalities including negative economic impacts, traffic problems and crowding, and societal and cultural problems.

Economic impact studies of mega-sporting events are often exaggerated by overestimating the economic gains and underestimating the costs involved for preparing the events (Barclay, 2009). Although mega-sporting events will receive heavy attention from the public and media, a simple cost benefit analysis often indicates that the costs of hosting the event exceed the positive and direct economic impacts related to increased tourist spending by a wide margin, and the presence of positive benefits depends on factors like improvements of infrastructure (B. Humphreys \& Prokopowicz, 2007). 
For example, based on a study of six Super Bowls that dated back to 1979, Porter (1999) found "no measurable impact on spending associated with the event. The projected spending and spillover benefits of regional impact models never materialize” (p. 61). He also found that hotel occupancy rate and retail sales in a host city are not statistically increased during the Super Bowl compared to similar dates in non-Super Bowl years (Porter, 1999). Other studies indicate little evidence that hosting sporting events for the sake of community development with public subsidies provided significant positive economic impacts (Hamilton \& Kahn, 1997; Rosentraub, 1994). Instead of economic gains, many cities that have hosted mega-sporting events have experienced a deficit after the events. For example, Preuss (2004) estimated that the Sydney Olympics Organizing Committee for the 2000 Summer Olympics Games experienced losses of more than \$45 million. A more recent example estimated that the 2010 Vancouver Winter Olympic Organizing Committee also spent more than it made to prepare for the games and ran a deficit of C\$48.1 million in 2008, compared to the C\$60.9 million surplus it had in 2006-2007 (“Olympics,” 2008). Upcoming host cities like London for the 2012 Summer Olympic Games and Sochi for the 2014 Winter Olympic Games are already reportedly facing financial difficulties to prepare for the Games (Andranovich, Burbank, \& Heying, 2010).

The costs of hosting mega-sporting events have increased significantly in recent years from the investment not only for constructing venues and developing all the infrastructures but also for the heightened security issue. Mega-events have reportedly become attractive targets for potential terror attacks after the event of September 11, 2001, causing physical protection programs in the sport facilities to become a critical infrastructure issue (Appelbaum, Adeland, \& Harris, 2005; Atkinson \& Young, 2002; Viuker, 2002). It may be difficult to collect these costs through sponsorship, media contracts, and ticket sales, possibly leading to higher taxes being levied from the local residents.

Sporting events are also likely to create some noneconomic cost problems such as traffic congestion, increasing crime rate, and law enforcement strain (Haynes, 2001; J. M. Humphreys \& Plummer, 1995). Coates and Humphreys (2002) found that some local residents felt the additional traffic, noise, and increased garbage were too high a price to pay for whatever benefits they may obtain by living near an arena or stadium. In addition, some previous studies discussed other societal and cultural problems including the negative influences on traditional family values (Mihalik \& Cummings, 1995), cultural commercialization (Witt, 1988), unfair relocation of local residents (Sweeney, 2009), and conflicts and antagonism between visitors and local residents because of different standards of living, economic welfare, and purchasing power gaps (Tosun, 2002). Local residents are often excluded from participation in the event due to high costs for consumption in mega-sporting events (Higham, 1999). For example, on the official fan-to-fan resale site run by the Vancouver Organizing Committee (VOC), seats for the gold medal hockey game between the US and Canada were offered for several thousand dollars apiece (Vancouver Olympics, 2010).

Mega-sporting events may also damage the image of the host city as a result of inadequate facilities or improper procedures (Dwyer et al., 2000; Getz, 1991; Tosun, 2002). In other words, host cities may lose more than they gain in terms of destination image. Capacity constraints, financial costs, displacement of local residents, and political activism have the potential of causing negative publicity. Displacement or removal of local residents takes place where cities are eager to capitalize on the destination image (Higham, 1999). For example, in advance of the 1988 Seoul Olympic Games, 720,000 local residents were forcibly and unfairly removed, thousands of low-income tenants and small businesses were forced out of Barcelona before the Olympic Games, and more than 9,000 homeless were arrested in the lead-up to the 1996 Olympics in Atlanta (Olds, 1998; Shapcott, 1998). Sweeney (2009) indicated that 1.5 million people were relocated and unfairly compensated as a part of infrastructure development programs of the Beijing Organizing Committee of the Olympic Games (BOCOG) for the 2008 Beijing Olympic Games in China.

Destruction of the physical and natural environment is another critical concern. Hosting megasporting events with the construction of sport facilities and development of infrastructure possibly causes environmental damage due to the use of nonrenewable resources, emission of toxic substances, 
and production and disposal of sport equipment (Jagemann, 2003). These negative physical and environmental impacts include changes in land use, pollution, and deterioration of cultural or historical resources (Dwyer et al., 2000; Rascher, 2002). Bess (1999) also demonstrated that architectural designs for megasize sport facilities forced a change in the locations of sport facilities from greenfield sites to brownfield sites created by demolishing other buildings.

\section{Purpose of the Study}

The purpose of this study was to build on existing knowledge by developing and testing a structural equation model to assess local residents' psychological support factors of mega-sporting events and how the psychological factors affect local residents' attitudes toward hosting future mega-sporting events. This study was conducted using the case of the 2012 Super Bowl that will be hosted in Indianapolis. This study sought to provide a theoretical model to examine local residents' psychological support factors using a structural equation model, which presents the understanding of local residents for supporting hosting mega-sporting events in the future.

\section{The Proposed Model}

The proposed model in this study has its conceptual and theoretical basis in social exchange theory and is developed from previous studies that focus on measuring psychological impacts for a hosting mega-sporting event (Delamere, 2001; Delamere, Wankel, \& Hinch, 2001; Fredline \& Faulkner, 2001; Fredline, Jago, \& Deery, 2003; Gursoy \& Kendall, 2006; Jurowski, Uysal, \& Williams, 1997) Specifically, these studies implied social exchange theory to explain the perceptions of possible direct or indirect impacts through mega-sporting events, which may depend on how local residents evaluate the exchanges in which they are involved.

Social exchange theory suggests social change and stability as a process of negotiated exchanges between parties (Emerson, 1976). This theory posits that all human relationships are formed by the use of a subjective cost-benefit analysis and the comparison of alternatives (Lee et al., 2009). For example, social exchange theory indicates that local residents are likely to support mega-sporting events as long as they can expect benefits of any development, and these expected benefits will exceed the expected costs. Although political leaders and event organizers frequently tend to ignore the possible negative externalities or impacts and glorify the expected positive externalities, hosting mega-sporting events are likely to stimulate both positive and negative externalities in several spheres, such as economic, tourism and related business, physical, sociocultural, psychological, and political impacts (Delamere, 2001; Fredline et al., 2003; Ritchie, 1984).

Social exchange theory has been utilized as an appropriate and effective foundation to study residents' perceptions for hosting mega-sporting events (Ap, 1992; Bryant \& Napier, 1981; Gursoy, Jurowski, \& Uysal, 2002; Jurowski et al., 1997; Perdue, Long, \& Kang, 1999). It is supported that this theory may explain residents' motivations for entering into an exchange or their lack of support for such an exchange (Deccio \& Baloglu, 2002). This theory suggests that the primary motivation for initiating exchange from the residents' perspectives is to improve the community's possible development by hosting a mega-sporting event. Kim, Gursoy, and Lee (2006) found that residents in South Korea believed that the 2002 FIFA World Cup would generate a high volume of economic and cultural benefits for the community before the event, but realized that the benefits, especially the economic gains, were lower than they had expected after the event. On the other hand, several previous studies have confirmed that there is likely to be a direct relationship between the positive evaluation of social and cultural impacts received by hosting sporting events and support for future events (Besculides, Lee, \& McCormick, 2002; Brunt \& Courtney, 1999; Lankford \& Howard, 1994). Positive evaluations of the results arising from the social exchange may reinforce the desire for future participation in the relationship. If the perceived benefits from events outweigh the costs, residents in the local community are likely to support and participate in future exchange relations (Ap, 1992). After hosting the event, positive evaluations of the event's social impacts are likely to lead to supportive attitudes toward future events (Besculides et al., 2002; Brunt \& Courtney, 1999; Madrigal, 1993).

While many of the previous studies focused on measuring economic and social externalities 
regarding hosting international levels of megasporting events and residents' reactions toward different sporting events, this study focused on the various psychological impacts in hosting a megasporting event such as the Super Bowl.

\section{Methods}

\section{Instrument Development}

The purpose of this study was to assess local residents' psychological support of mega-sporting events and identify which factors of support affect local residents' attitudes toward hosting future mega-sporting events. This main data collection method of this study was a self-administered paper survey that consisted of three pages and a total of 41 items. To develop the survey, there were two pilot data collections to test specific aspects of the questionnaire. The primary basis for the initial item pool came from a similar study of perceptions of a women's professional golf event (Lee et al., 2009) as well as additional items from other studies of residents' perceptions of mega-events (Delamere, 2001; Delamere et al., 2001; Fredline \& Faulkner, 2001; Fredline et al., 2003; Gursoy et al., 2002; Gursoy \& Kendall, 2006; Milnthorp, 2002; Winters, 2004). The items developed from this literature review were measured on a 7-point Likert-type scale to assess the level of agreement to statements pertaining to perceived impact of a mega-sporting event. For example, respondents were asked to rate the level of agreement with the statement "I believe hosting a mega-event in my city will bring positive economic impact” from "strongly disagree” (1 on the scale) to "strongly agree" (7 on the scale). Each of the items followed the same pattern.

\section{Pilot Tests}

Following the generation of the initial item pool, further development of the questionnaire entailed several steps. To determine the reliability of the proposed factors, an initial pilot study was conducted to test the items and function of the survey. This sample consisted of faculty and undergraduate students from a large Midwestern university $(n=73)$. Since the questionnaires used in this study were modified from different economic and social impact contexts, content validity was a concern.
The content validity of the questionnaires was verified using a panel of experts comprised of faculty and practitioners in sport management. Five panel members were asked to review each of the questionnaires carefully to determine whether the individual items adequately represented the domains of the constructs. All of the experts agreed that the original questionnaires selected and modified by the researchers were acceptable for use in data collection.

The primary objective from the first pilot was to examine the function and consistency of the proposed items and factor structure. Each proposed factor and corresponding list of items were examined for reliability independently of the other factors and their corresponding items. Cronbach's $\alpha$ was calculated for each factor, and the factor loadings for each item were also determined. The results from the first pilot study are listed in Table 1 . The reliability scores (Cronbach's $\alpha$ ) for six of the seven proposed factors were stable (Image and Awareness $=0.889$, Leisure Resource Development $=0.876$, Positive Economic Impact $=0.888$, Negative Economic Impact $=0.725$, Traffic Problems and Crowding $=0.845$, Societal and Cultural Problems $=0.865$ ) with one showing weak reliability (Infrastructure Development $=0.451$ ).

Once the consistency within each factor was determined, a confirmatory factor analysis (CFA) was conducted in a second pilot study with additional respondents from the same Midwestern university $(n=170)$. The objective of this pilot test was to go beyond factor reliability and further test the proposed model structure to examine if the factors correlated to each other as expected. Utilizing the software program EQS (Bentler, 2005), the level of fit between the proposed model and the collected data was determined using the indices recommended by $\mathrm{Hu}$ and Bentler (1995, 1999), comparative fit index (CFI), normed fit index (NFI), root mean square error of approximation (RMSEA), and standardized root mean square residual (SRMR). The Satorra-Bentler chi-square $\left(\mathrm{SB} x^{2}\right)$ was used in the analysis due to its ability to minimize the effects of multivariate kurtosis found in the data (Satorra \& Bentler, 1994). To test construct validity, item factor loadings were investigated for appropriate strength as well as tested for appropriate structure. Adjustments to the model were made after careful consideration of the item 
Table 1

List of Factors and Items Including Factor Loadings and Reliability Scores

\begin{tabular}{|c|c|c|c|c|}
\hline I believe hosting a Super Bowl will: & $\begin{array}{l}\text { 1st Pilot } \\
\text { Factor } \\
\text { Loadings }\end{array}$ & $\begin{array}{l}\text { 1st Pilot } \\
\text { Reliability }\end{array}$ & $\begin{array}{l}\text { 2nd Pilot } \\
\text { Factor } \\
\text { Loadings }\end{array}$ & $\begin{array}{l}\text { 2nd Pilot } \\
\text { Reliability }\end{array}$ \\
\hline Image and awareness enhancement & & 0.889 & & 0.887 \\
\hline $\begin{array}{l}\text { Bring more media attention to Indianapolis area. } \\
\text { Increase opportunity to inform Indianapolis to }\end{array}$ & 0.785 & & 0.823 & \\
\hline the world. & 0.746 & & 0.750 & \\
\hline Increase recognition of Indianapolis internationally. & 0.709 & & 0.632 & \\
\hline Increase the visibility of the Indianapolis area. & 0.732 & & 0.623 & \\
\hline Enhance Indianapolis beauty. & 0.680 & & 0.711 & \\
\hline $\begin{array}{l}\text { Improve a positive of impression of Indiana- } \\
\text { polis from other state residents or international } \\
\text { residents. }\end{array}$ & 0.818 & & 0.791 & \\
\hline $\begin{array}{l}\text { Enhance image of Indianapolis as a major city } \\
\text { or "first-tier" city. }\end{array}$ & 0.749 & & 0.678 & \\
\hline a Super Bowl. & 0.575 & & 0.643 & \\
\hline Leisure resource development & & 0.876 & & 0.784 \\
\hline $\begin{array}{l}\text { Increase leisure facilities construction in } \\
\text { Indianapolis area. }\end{array}$ & 0.705 & & 0.530 & \\
\hline $\begin{array}{l}\text { Increase sporting facilities in Indianapolis area. } \\
\text { Increase sport spectator information facilities in }\end{array}$ & 0.854 & & 0.834 & \\
\hline Indianapolis area. & 0.925 & & 0.775 & \\
\hline $\begin{array}{l}\text { Increase number of cultural events in Indianapolis } \\
\text { area. }\end{array}$ & 0.713 & & 0.594 & \\
\hline Infrastructure development & & 0.451 & & 0.765 \\
\hline $\begin{array}{l}\text { Bring an opportunity to redevelop Indianapolis } \\
\text { area and its infrastructure. }\end{array}$ & 0.645 & & 0.814 & \\
\hline $\begin{array}{l}\text { Improve conditions of traffic systems in } \\
\text { Indianapolis area. }\end{array}$ & 0.493 & & 0.465 & \\
\hline Positive economic impact & & 0.888 & & 0.720 \\
\hline Bring positive economic impact into Indiana. & 0.991 & & 0.642 & \\
\hline $\begin{array}{l}\text { Stimulate related business like hotel, restaurant, } \\
\text { and other tourism business. }\end{array}$ & 0.917 & & 0.997 & \\
\hline Bring new business into Indianapolis area. & 0.684 & & 0.696 & \\
\hline $\begin{array}{l}\text { Generate and provide many new job opportunities } \\
\text { to Indiana residents. }\end{array}$ & 0.688 & & 0.833 & \\
\hline $\begin{array}{l}\text { Make people spend more money in } \\
\text { Indianapolis area. }\end{array}$ & 0.607 & & 0.496 & \\
\hline Negative economic impact & & 0.725 & & 0.778 \\
\hline Make residents pay more tax. & 0.505 & & 0.756 & \\
\hline Increase the price of real estate in Indianapolis area. & 0.609 & & 0.802 & \\
\hline Increase the price of goods and services. & 0.983 & & 0.749 & \\
\hline Traffic problems and crowding & & 0.845 & & 0.719 \\
\hline Increase traffic congestion. & 0.843 & & 0.798 & \\
\hline Increase crowding in Indianapolis area. & 0.852 & & 0.997 & \\
\hline Societal and cultural problems & & 0.865 & & 0.782 \\
\hline $\begin{array}{l}\text { Increase crime rates in our community. } \\
\text { Increase law enforcement strain in Indianapolis }\end{array}$ & 0.828 & & 0.731 & \\
\hline $\begin{array}{l}\text { Increase law enforcement strain in Indianapolis } \\
\text { area. }\end{array}$ & 0.542 & & 0.669 & \\
\hline Increase pollution problem. & 0.798 & & 0.734 & \\
\hline $\begin{array}{l}\text { Bring conflicts and antagonism against out-of-state } \\
\text { spectators or foreign spectators. }\end{array}$ & 0.762 & & 0.358 & \\
\hline Increase vandalism. & 0.833 & & 0.780 & \\
\hline
\end{tabular}


and the Lagrange multiplier (LM) test (Byrne, 2006; Kline, 2005).

The initial results from the second pilot test revealed a moderately weak fit $\left[\mathrm{SB}^{2}(384)=724.60\right.$, $\mathrm{CFI}=0.789, \mathrm{NFI}=0.695$, $\mathrm{SRMR}=0.086$, $\mathrm{RMSEA}=$ 0.093]. The factor loadings from this first analysis are included in Table 1. Examination of the LM test reveals several items that share common error variance with items associated with different factors. After several iterative steps, the model was adjusted slightly to reflect these covariances. Several items were found to relate closely to other factors, for example, the items in the factor "infrastructure development" were closely related to the items in the "sport resource development," indicating that the respondents view these types of development as closely related when considering the benefits of a mega-sporting event such as the Super Bowl. Table 2 displays the changes in the model and the adjusted factor loadings. These changes increase the fit to a moderate level $\left[\mathrm{SB}^{2}(356)=584.03, \mathrm{CFI}=0.849\right.$, $\mathrm{NFI}=0.774, \mathrm{SRMR}=0.080, \mathrm{RMSEA}=0.071]$.

Another important consideration when examining a model is discriminant validity. Factors should correlate with each other but not so strongly that they represent the same construct (i.e., <0.85; Kline,

Table 2

Adjusted Factors and Item List With Factor Loadings

I believe hosting a Super Bowl will:

2nd Pilot Factor

2nd Pilot

Loadings

Reliability

\begin{tabular}{|c|c|c|}
\hline \multicolumn{3}{|l|}{ Image and awareness enhancement } \\
\hline Bring more media attention to Indianapolis area. & 0.807 & 0.826 \\
\hline Increase opportunity to inform Indianapolis to the world. & 0.737 & 0.780 \\
\hline Increase recognition of Indianapolis internationally. & 0.628 & 0.777 \\
\hline Increase the visibility of the Indianapolis area. & 0.651 & Dropped \\
\hline Enhance Indianapolis beauty. & 0.755 & Dropped \\
\hline $\begin{array}{l}\text { Improve a positive impression of Indianapolis from other state residents or } \\
\text { international residents. }\end{array}$ & 0.780 & 0.813 \\
\hline Enhance image of Indianapolis as a major city or “first-tier” city. & 0.675 & 0.748 \\
\hline I am proud to live in the city that will host a Super Bowl. & 0.619 & Dropped \\
\hline Leisure resource development & & \\
\hline Increase leisure facilities construction in Indianapolis area. & 0.537 & 0.798 \\
\hline Increase sporting facilities in Indianapolis area. & 0.787 & 0.852 \\
\hline Increase sport spectator information facilities in Indianapolis area. & 0.805 & 0.856 \\
\hline Increase number of cultural events in Indianapolis area. & 0.613 & 0.645 \\
\hline Business development & & \\
\hline Bring an opportunity to redevelop Indianapolis area and its infrastructure. & 0.843 & 0.790 \\
\hline Improve conditions of traffic systems in Indianapolis area. & 0.514 & Dropped \\
\hline Bring new business into Indianapolis area. & 0.713 & 0.819 \\
\hline Generate and provide many new job opportunities to Indiana residents. & 0.725 & 0.784 \\
\hline Positive economic impact & & \\
\hline Bring positive economic impact into Indiana. & 0.740 & 0.778 \\
\hline Stimulate related business like hotel, restaurant, and other tourism business. & 0.846 & 0.691 \\
\hline Make people spend more money in Indianapolis area. & 0.548 & 0.750 \\
\hline Negative economic impact & & \\
\hline Make residents pay more tax. & 0.640 & 0.721 \\
\hline Increase the price of real estate in Indianapolis area. & 0.756 & 0.754 \\
\hline Increase the price of goods and services. & 0.802 & 0.808 \\
\hline Traffic problems and crowding & & 0.719 \\
\hline Increase law enforcement strain in Indianapolis area. & 0.804 & 0.836 \\
\hline Increase crowding in Indianapolis area. & 0.891 & 0.765 \\
\hline Hinder my ability to get around for my personal needs. ${ }^{a}$ & & 0.717 \\
\hline Societal and cultural problems & & 0.782 \\
\hline Increase crime rates in our community. & 0.728 & 0.838 \\
\hline Increase pollution problem. & 0.735 & 0.791 \\
\hline Bring conflicts and antagonism against out-of-state spectators or foreign spectators. & 0.561 & Dropped \\
\hline Increase vandalism. & 0.729 & 0.858 \\
\hline
\end{tabular}

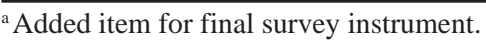


2005). It was assumed to this point that these factors are all related to each other as representative of a single higher psychological notion of the impacts of the Super Bowl in the respondents' community. An examination of the correlations shows moderate relationships in two categories. These categories represent the positive impacts as slightly different from the negative impacts. These correlations between factors are listed in Table 3.

\section{Sample and Procedure}

The primary data were collected for 5 days in a shopping mall in downtown Indianapolis, Indiana, during the month of April 2010. Subjects were selected using a systemic sampling technique and restricted to only adults 18 years of age and older. The collectors intercepted every 10th person entering at the front of the main gate of the shopping mall and asked them to complete a paper survey. Upon agreement, they were handed a clipboard with the survey and a writing tool. The collected data were analyzed using the Statistical Packages for the Social Sciences (SPSS 17.0) program and EQS (Bentler, 2005).

\section{Data Analyses}

A confirmatory factor analysis (CFA) was used to assess the consistency between the hypothesized structure and the structure found in the data. This analysis was conducted using the procedures outlined in Byrne (2006) and Hatcher (1994). To assess the level of Indianapolis residents' psychological support for hosting the Super Bowl, structural equation modeling was used to test the proposed structure as found in Figure 1. Residents' attitudes toward future development and sport events was measured using three statements on a 7-point Likert-type agreement scale: "I believe the city and/or state should host more mega-sized sporting events," "I believe the city and/or state should invest more for constructing or renovating sport infrastructures," and "I support hosting the Super Bowl in 2012.”

\section{Results}

Descriptive statistics were calculated for each of the continuous sociodemographic variables that are summarized in Table 4. The total number of subjects used for the research was 413, comprised of 195 males (47.2\%) and 218 females (52.8\%), and most reported were at the age of $18-30(n=195,47.2 \%)$. Specifically, the age of the subject ranged from 18 to 74 years old $(M=37.97, S D=13.07)$. More than 93\% of the respondents were between 21 and 50 years old. For the status of ethnicity, the majority of survey respondents were Caucasian $(n=313,75.8 \%)$, followed by African American ( $n=44,10.7 \%)$, Hispanic ( $n=16,3.9 \%)$, Asian ( $n=8,1.9 \%)$, Native American ( $n=4,1.0 \%)$, and others $(n=28,6.8 \%)$. Based on US census data from 2010, gender and age were representative of the population. When examining the responses for ethnicity, it appears that there was an oversampling of Caucasian compared to Marion County (63\%) but in line with estimates for the greater Indianapolis area (73\%) (Marion and contagious counties). Zip codes were collected and

Table 3

Pretest and Main Data Correlations Between Latent Variables

\begin{tabular}{|c|c|c|c|c|c|c|c|}
\hline & $\begin{array}{l}\text { Image and } \\
\text { Awareness }\end{array}$ & $\begin{array}{c}\text { Resource } \\
\text { Development }\end{array}$ & $\begin{array}{c}\text { Business } \\
\text { Development }\end{array}$ & $\begin{array}{l}\text { Positive } \\
\text { Economic } \\
\text { Impact }\end{array}$ & $\begin{array}{l}\text { Negative } \\
\text { Economic } \\
\text { Impact }\end{array}$ & $\begin{array}{c}\text { Traffic } \\
\text { Problems and } \\
\text { Crowding }\end{array}$ & $\begin{array}{l}\text { Societal and } \\
\text { Cultural } \\
\text { Problems }\end{array}$ \\
\hline Image and awareness & - & $0.613 *$ & $0.903 *$ & $0.800 *$ & $0.317 *$ & 0.215 & 0.086 \\
\hline Resource development & $0.691 *$ & - & $0.567 *$ & $0.681^{*}$ & $0.485^{*}$ & 0.268 & 0.311 \\
\hline Business development & $0.884 *$ & $0.709 *$ & - & $0.694 *$ & $0.371^{*}$ & 0.178 & 0.212 \\
\hline Positive economic impact & $0.900 *$ & $0.820 *$ & $0.725^{*}$ & - & $0.422 *$ & 0.339 & 0.213 \\
\hline Negative economic impact & $0.334 *$ & $0.398 *$ & $0.450^{*}$ & $0.421 *$ & - & $0.545^{*}$ & $0.467 *$ \\
\hline $\begin{array}{l}\text { Traffic problems and } \\
\text { crowding }\end{array}$ & $0.247^{*}$ & 0.134 & $0.246^{*}$ & $0.294 *$ & $0.591^{*}$ & - & $0.566^{*}$ \\
\hline $\begin{array}{l}\text { Societal and cultural } \\
\text { problems }\end{array}$ & $0.135^{*}$ & 0.115 & $0.294 *$ & 0.135 & $0.660^{*}$ & $0.867 *$ & - \\
\hline
\end{tabular}




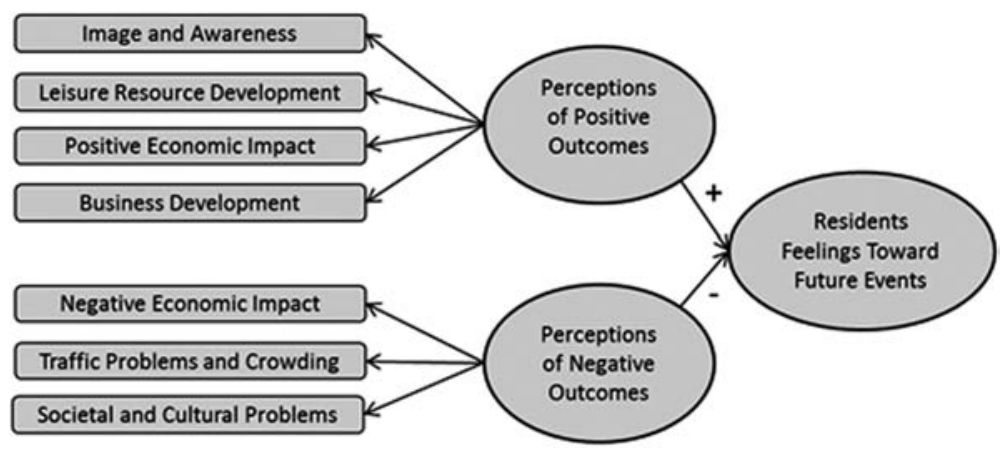

Figure 1. Proposed model.

analyzed, revealing that $52.3 \%$ were from Indianapolis and $83.1 \%$ were from the greater Indianapolis area. Only 3.5\% were from out of state and were excluded from the analysis.

Table 4.

Sociodemographic Characteristics by Frequency and Percentage

\begin{tabular}{|c|c|c|}
\hline Characteristics $(n=413)$ & Frequency & Percent \\
\hline \multicolumn{3}{|l|}{ Age } \\
\hline 18-30 & 195 & 47.2 \\
\hline $31-40$ & 123 & 29.8 \\
\hline $41-50$ & 69 & 16.7 \\
\hline $51-60$ & 21 & 5.1 \\
\hline 61 or above & 5 & 1.2 \\
\hline \multicolumn{3}{|l|}{ Gender } \\
\hline Male & 195 & 47.2 \\
\hline Female & 218 & 52.8 \\
\hline \multicolumn{3}{|l|}{ Ethnicity } \\
\hline African American & 44 & 10.7 \\
\hline Asian & 8 & 1.9 \\
\hline Caucasian/Non-Hispanic & 313 & 75.8 \\
\hline Hispanic & 16 & 3.9 \\
\hline Native American & 4 & 1 \\
\hline Other & 28 & 6.8 \\
\hline \multicolumn{3}{|l|}{ Football is favorite sport } \\
\hline Yes & 173 & 41.9 \\
\hline No & 240 & 58.1 \\
\hline \multicolumn{3}{|c|}{ Hours of watching NFL per week } \\
\hline Less than $1 \mathrm{~h}$ & 85 & 20.6 \\
\hline $1-3 \mathrm{~h}$ & 110 & 26.6 \\
\hline $4-6 \mathrm{~h}$ & 130 & 31.5 \\
\hline $7-9 \mathrm{~h}$ & 66 & 16 \\
\hline More than $9 \mathrm{~h}$ & 22 & 5.3 \\
\hline \multicolumn{3}{|c|}{ Favorite sport programming network } \\
\hline ESPN Network & 237 & 57.4 \\
\hline Fox Sports Network & 47 & 11.4 \\
\hline National Broadcast & 97 & 23.5 \\
\hline Other & 32 & 7.7 \\
\hline
\end{tabular}

\section{Measurement Model}

The first step in the data analysis was to conduct the CFA, comparing the model refined through the pilot tests with the structure of the collected data. The results from the initial analysis show a moderate fit similar to that of the second pilot study $\left[\mathrm{SB}^{2}(384)=1204.57, \mathrm{CFI}=0.854, \mathrm{NFI}=0.815\right.$, $\mathrm{SRMR}=0.079$, RMSEA $=0.072]$. Examination of the factor loadings, evidence of additional common error variance between items, and careful review of wording and potential meaning led to the elimination of five items. This also helped achieve a parsimonious model without sacrificing the reliability of the model. The simplified model revealed a good fit to the data $\left[\mathrm{SB}^{2}(229)=532.46\right.$, CFI $=0.927$, $\mathrm{NFI}=0.896, \mathrm{SRMR}=0.053, \mathrm{RMSEA}=0.057]$. The factor loadings from this model are presented in Table 2. Construct validity was again checked, and the correlations between latent factors are presented in Table 3. Further evidence was shown in the correlations that there are two factors, positive and negative structures, to residents' perceptions of outcomes in hosting a Super Bowl.

\section{Final Structural Model}

In order to test the second part of the study objective, to determine which factors of support affect feelings toward future development, a structural equation model was tested. Figure 2 displays the standardized loadings for the proposed model in a figural representation of the variables tested in the model. The four latent variables that influence residents' positive perceptions of outcomes all loaded 


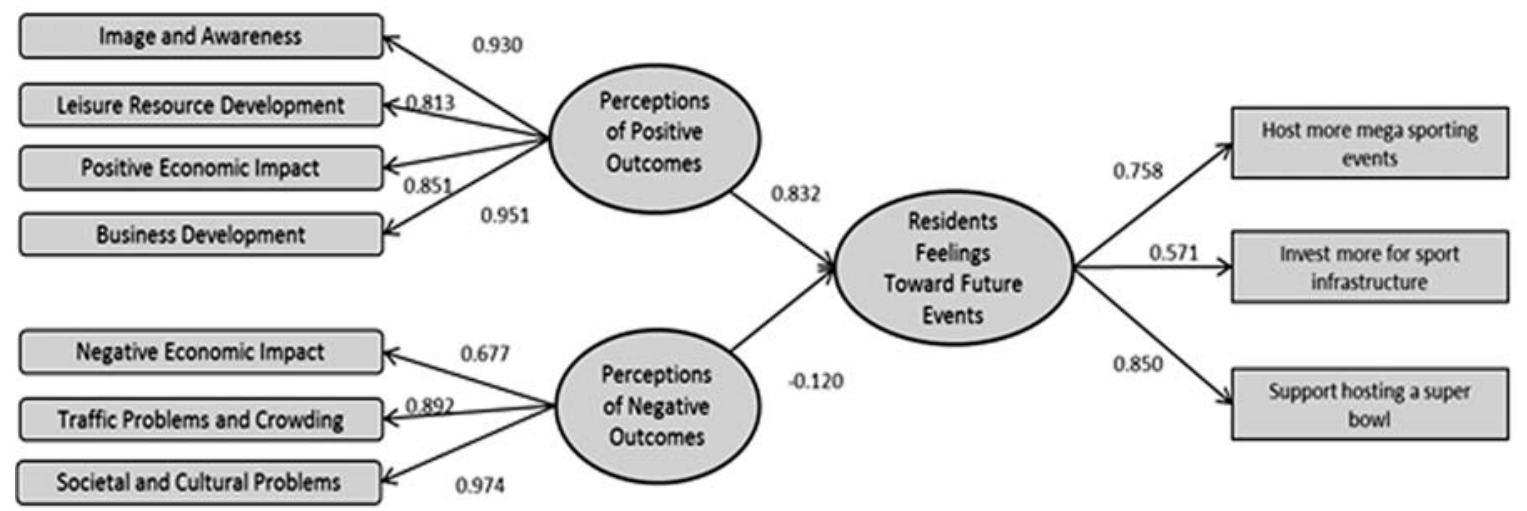

Figure 2. Results of structural equation modeling.

relatively well on the latent variable of residents' feelings toward future events. Two of the three latent variables that influence negative perceptions of outcomes loaded well, with only perceptions of negative economic impact not loading strongly (0.677) on residents' feelings toward future events. Support for hosting the Super Bowl and support for hosting more mega-sporting events loaded well, while investing more in sport infrastructure was not quite as well. Overall, positive perceptions have a strong relationship with feelings toward future events, while negative perceptions do not necessarily lead to a decrease in feelings toward the future; however, it was still a significant relationship in the model.

\section{Discussion and Conclusions}

Communities are increasingly drawn to host mega-sporting events due to promises of positive impacts including economic, resource development, infrastructure development, and others. Although economic impact studies are often used as a monetary justification for hosting events, these methods are often criticized for their controversial methodologies (Berrett, 2001; Cornelissen, 2004; Crompton, 2006; Desbordes, 2007). It has been suggested that studies of the impacts of mega-sporting events should include psychosocial impacts to gauge the level of acceptance by the local community (Bob \& Swart, 2009, Crompton, 2004). The purpose of this study was to assess local residents' psychological support of mega-sporting events and identify which factors of support affect local residents' attitudes toward hosting future mega-sporting events.
The model presented supports the impact of residents' perceptions of the event on feelings toward hosting future events. These impacts were demonstrated through perceptions of image and awareness, resource development, economic impact, business development, societal concerns, and traffic and crowding. The model also supports the findings of Lee et al. (2009) of a seven-factor model with four positive and three negative components. The final list of items used for this study captures the psychological relationships within the study sample. The refinement of this scale using two pilot studies provides a stable inventory that is theoretically and empirically sound. One interesting adjustment to the proposed model was the psychological relationship between infrastructure development and business development. New businesses, new jobs, and infrastructure redevelopment were closely related (see Table 2), but separate from leisure resource development (see Table 3). This result is slightly different from the relationship of perceptions of infrastructure and sport facility availability as suggested previously (Noll \& Zimbalist, 1997; Turco, 1995). Sport and leisure development is psychologically different than infrastructure development for the study sample. Figure 2 shows that the relationship between leisure development and future support is the weakest of the four positive factors. Residents are somewhat more willing to support jobs and businesses than to support leisure and sport development.

This study was conducted 18 months prior to hosting the 2012 Super Bowl in Indianapolis, which may impact the perceptions of the event. Residents have not had any experience with any of the preparations 
for the event, so they may not have accurate perceptions of the negative impacts such as traffic, crowding, or societal concerns. The SEM model shows that positive perceptions were highly related to feelings toward future events, while negative perceptions had little relationship to these feelings. Future studies would benefit looking at feelings both just prior to the event, just following the event, and again after an extended time. These changes in perception can go a long way to helping find additional support in hosting sporting events and identifying ways to better plan and present future events.

When examining the SEM results (see Fig. 2), it can be seen that the four positive factors (image and awareness, leisure resource development, positive economic impact, and business development) were highly and fairly equally related through the perceptions of positive outcomes latent factor. However, when looking at the negative items, traffic and societal concerns are highly related, but negative economic impact was not. This result might reveal the higher concern about immediate negative actions rather than dealing with long-term changes in the economic situation, that is, traffic during the event or increased crime due to the number of people in town for the event. Similarly, residents are proud to host a Super Bowl and support future sporting events but feel less strongly about investing more in the sport infrastructure for future events. This perhaps signifies a slight indifference toward future investment, which can have an impact on organizers looking to garner resident support for investing in sport facilities.

\section{Implications and Future Research}

The current study has clarified positive and negative externalities on a host community's perceptions to support hosting a mega-sporting event, and its assessment of the model has demonstrated how positive externalities affect the residents' willingness to support hosting a mega-sporting event. Since residents' involvement and support have become more important to bid and prepare for a sporting event such as the Olympic Games (Gursoy \& Kendall, 2006), event governing bodies and administration should focus more on positive externalities to increase the level of residents' support. As it is widely accepted, the host community governing bodies should develop plans for fostering positive externalities and feelings toward the sporting event, and accordingly, they should rely most heavily on the positive outcomes. Although the negative factors were not as strongly related based on the results of the current study, they were still significant indicators of residents' perceptions toward future sporting events. The part of the plans pertaining to growing community support should include ways that the negative impacts might be mitigated.

Host governing bodies should focus on these positive and psychological externalities to stimulate the economic benefits of hosting an event to the residents. Presentation of information concerning both psychological and economic benefits to the local residents may enhance residents' perception levels toward hosting more future sporting events with possible developments of local business and infrastructure systems. It is also important to identify the potential impact of negative perceptions and include messages to minimize these impacts. Efforts to communicate to the residents in the host community(s) should be targeted to highlight the factors that have the strongest impact on positive perceptions while educating the residents about efforts to minimize potential negative impacts.

As suggested by Lee et al. (2009), the results of this study also confirm the social exchange theory, which explains that local residents who perceived positive externalities (i.e., new business, new job, and infrastructure development) from hosting the event are supportive of future sporting events. This result emphasized that sporting event host governing bodies should clearly identify and provide possible positive and negative externalities to the residents and induce their willingness to support hosting future mega-sporting events.

While this study does have implications for hosts and managers of mega-events, there are some limitations in this study. In many ways, this is a case study involving the location and specific event of Superbowl XLVI. The model proposed and analyzed here would need to be further tested and validated in other locations and for other events. Additionally, the data for this study were collected in a public retail space, which limits the true generalizability of the findings.

A couple of recommendations for future studies have been drawn from the current study. As mentioned, a comparative study before and after 
the event is recommended to assess the changes in perception of residents for hosting sporting events. The results of local residents' perception differences before and after the event with their expected and perceived impacts may have an influence on hosting future sporting events. This study has a limited sample in choosing only residents in the Super Bowl host city. Expanding the sample to a wider variety of other cities' residents around the US is necessary for future studies, which would provide different levels of interest in hosting mega-sporting events.

\section{References}

Andranovich, G., Burbank, M., \& Heying, C. (2010). Political economy of the Olympic Games. In C. Santo \& G. Mildner (Eds.), Sport and public policy: Social, political, and economic perspectives (pp. 185-200). Champaign, IL: Human Kinetics.

Ap, J. (1992). Residents' perceptions on tourism impacts. Annals of Tourism Research, 19(4), 665-690. DOI: 10.1016/0160-7383(92)90060-3.

Appelbaum, S. H., Adeland, E., \& Harris, J. (2005). Management of sports facilities: Stress and terrorism since 9/11. Management Research News, 28(7), 69-83. DOI: 10.1108/01409170510784896.

Atkinson, M., \& Young, K. (2002). Terror games: Media treatment of security issues at the 2002 Winter Olympic Games. International Journal of Olympic Studies, 9, 53-78. DOI: 10.1080/14775080310001690495.

Baade, R., \& Matheson, V. (2004). The quest for the cup: Assessing the economic impact of the World Cup. Regional Studies, 38(4), 343-354. DOI: 10.1080/ 03434002000213888.

Barclay, J. (2009). Predicting the costs and benefits of mega sporting events: Misjudgement of Olympic proportions? Economic Affairs, 29(2), 62-66. DOI: 10.1111/j.14680270.2009.01896.X.

Bentler, P. M. (2005). EQS program manual. Encino, CA: Multivariate Software, Inc.

Berrett, T. (2001). The economic significance of amateur sport and active recreation in Edmonton in 2000. Edmonton, Alberta: Caminata Consulting.

Besculides, A., Lee, M. E., \& McCormick, P. J. (2002). Residents' perceptions of the cultural benefits of tourism. Annals of Tourism Research, 29(2), 303-319. DOI: 10.1016/S0160-7383(01)00066-4.

Bess, P. (1999). City baseball magic: Plain talk and uncommon sense about cities and baseball parks. The Public Interest, 22, 45.

Blake, A. (2005). The economic impact of the Olympics. Unpublished discussion paper, Department for Culture, Media and Sport, Christel DeHaan Tourism and Travel Research Institute, Nottingham University Business School, UK.

Bob, U., \& Swart, K. (2009). Resident perceptions of the 2010 FIFA Soccer World Cup stadia development in
Cape Town. Urban Forum, 20(1), 47-59. DOI: 10.1007/ s12132-009-9052-2.

Broudehoux, A. (2007). Delirious Beijing. In M. Davis \& D. Monk (Eds.), Evil paradises: Dream worlds of neoliberalism (pp. 87-101). New York: New Press.

Brunt, P., \& Courtney, P. (1999). Host perceptions of sociocultural impacts. Annals of Tourism Research, 26(3), 493-515. DOI: 10.1016/S0160-7383(99)00003-1.

Bryant, E. G., \& Napier, T. L. (1981). The application of social exchange theory to the study of satisfaction with outdoor recreation facilities. In T. L. Napier, Outdoor recreation planning, perspectives, and research (pp. 83-98). Dubuque, IA: Kendall Hunt.

Burns, J. P. A., Hatch, J. H., \& Mules, T. J. (1986). The Adelaide Grand Prix: The impact of a special event. Adelaide: Center for South Australian Economic Studies.

Buss, W. (2007). Implications of social, political and economic insights for South Africa in 2010 gained from FIFA World Cup in Germany 2006. Paper delivered at the University of Johannesburg, 4 November.

Byrne, B. M. (2006). Structural equation modeling with EQS (2nd ed.). Manwah, NJ: Lawrence Earlbaum.

Carriere, J., \& Demaziere, C. (2002). Urban planning and flagship development projects: Lessons from Expo 98, Lisbon. Planning Practice and Research, 17(1), 69-79. DOI: 10.1080/02697450220125096.

Coates, D., \& Humphreys, B. (2002). Voting on stadium and arena subsidies. Paper presented at the Public Choice Society Meetings, San Diego, CA.

Cornelissen, S. (2004). Sport mega-events in Africa: Processes, impacts and prospects. Tourism and Hospitality Planning and Development, 1(1), 39-55. DOI: 10.1080/1479053042000187793.

Crompton, J. L. (2004). Beyond economic impact: An alternative rationale for the public subsidy of major league sports facilities. Journal of Sport Management, 18(1), $40-58$.

Crompton, J. L. (2006). Economicimpact studies: Instruments for political shenanigans? Journal of Travel Research, 45(1), 67-82. DOI: 10.1177/0047287506288870.

Deccio, C., \& Baloglu, S. (2002). Non host community resident reactions to the 2002 Winter Olympics: The spillover impacts. Journal of Travel Research, 41(1), 46-56. DOI: $10.1177 / 0047287502041001006$.

Delamere, T. (2001). Development of a scale to measure resident attitudes toward the social impacts of community festivals, Part II: Verification of the scale. Event Management, 7(1), 25-38.

Delamere, T., Wankel, L. M., \& Hinch, T. D. (2001). Measuring resident attitudes toward the social impact of community festivals, Part I: Item generation and purification of the measure. Event Management, 7(1), 11-24.

Desbordes, M. (2007). A review of the economic impact studies done on the Tour de France: Methodological aspects and first results. International Journal of Sport Management and Marketing, 2(5/6), 526-540.

Dwyer, L., Mellor, R., Mistilis, N., \& Mules, T. (2000). A framework for assessing "tangible" and "intangible" 
impacts of events and conventions. Event Management, 6(3), 175-189.

Emerson, R. M. (1976). Social exchange theory. Annual Review of Sociology, 2(1), 335-362. DOI:10.1146/ annurev.so.02.080176.002003.

Fredline, E., \& Faulkner, B. (2001). Residents' reactions to the staging of major motorsport events within their communities: A cluster analysis. Event Management, 7(2), 103-114.

Fredline, L., Jago, L., \& Deery, M. (2003).The development of a generic scale to measure the social impacts of events. Event Management, 8(1), 23-37.

Getz, D. (1991). Assessing the economic impacts of festivals and events: Research issues. Journal of Applied Recreation Research, 16(1), 61-77.

Goldman, G., \& Nakazawa, A. (1997). Determining economic impacts for a community. Economic Development Review, 15(1), 48-51.

Gratton, C., Dobson, N., \& Shibli, S. (2000). The economic importance of major sports events: A case-study of six events. Managing Leisure, 5(1), 17-28. DOI: 10.1080/136067100375713.

Gratton, C., Shilbli, S., \& Coleman, R. (2006). The economic impact of major sports events: A review of ten events in the UK. Sociological Review, 54(2), 41-58. DOI: 10.1111/j.1467-954X.2006.00652.x.

Gursoy, D., Jurowski, C., \& Uysal, M. (2002). Residents' attitude: A structural modeling approach. Annual s of Tourism Research, 29(1), 79-105. DOI: 10.1016/S01607383(01)00028-7.

Gursoy, D., \& Kendall, K. W. (2006). Hosting mega events: Modeling locals' support. Annals of Tourism Research, 33(3), 603-623. DOI: 10.1016/j.annals.2006.01.005.

Hall, C. M. (1992). Hallmark tourist events: Impacts, management, and planning. London: Bellhaven Press.

Hamilton, B., \& Kahn, P. (1997). Baltimore’s Camden Yards ballparks. In R. Noll \& A. Zimbalist, Sports, taxes, and jobs: The economic impact of sports teams and stadiums (pp. 245-281). Washington, DC: The Brookings Institution.

Hatcher, L. (1994). A step by step approach to using SAS for factor analysis and structural equation modeling. Cary, NC: SAS Publishing.

Haxton, P. (1999). Community involvement and the Olympic Games: A review of related research. Paper presented at the 7th International Post Graduate Seminar on Olympic Studies, Greece.

Haynes, J. (2001). Socio-economic impact of the Sydney 2000 Olympic Games. Retrieved January 27, 2010, from http://olympicstudies.uab.es/pdf/od013 eng.pdf

Higham, J. (1999). Commentary sport as an avenue of tourism development: An analysis of the positive and negative impacts of sport tourism. Current Issues in Tourism, 2(1), 82-90. DOI: 10.1080/13683509908667845.

Hiller, H. (1990). The urban transformation of a landmark event: The 1988 Calgary Winter Olympics. Urban Affairs Quarterly, 26(1), 118-137. DOI: 10.1177/004208169002 600106.

Hotchkiss, J. L., Moore, R. E., \& Zobay, S. M. (2003). Impact of the 1996 Summer Olympic Games on employment and wages in Georgia. Southern Economic Journal, 69(3), 691-704.

Hu, L. T., \& Bentler, P. M. (1995). Evaluating model fit. In R. H. Hoyle (Ed.). Structural equation modeling: Concepts issues and applications (pp. 76-99). Thousand Oaks, CA: Sage.

Hu, L. T., \& Bentler, P. M. (1999). Cutoff criteria for fit indexes in covariance structure analysis: Conventional criteria versus new alternatives. Structural Equation Modeling, 6(1), 1-55. DOI: 10.1080/10705519909540118.

Humphreys, B., \& Prokopowicz, S. (2007). Assessing the impact of sports mega-events in transition economies: EURO 2012 in Poland and Ukraine. International Journal of Sport Management and Marketing, 2(5-6), 496-509.

Humphreys, J. M. (1994). The economic impact of hosting Super Bowl XXVIII on Georgia. Georgia Business and Economic Conditions, 54(3), 18-21.

Humphreys, J. M., \& Plummer, M. K. (1995). The economic impact on the State of Georgia of hosting the 1996 Summer Olympic Games [Executive summary prepared for the Atlanta Committee for the Olympic Games]. Athens: University of Georgia, Selig Center for Economic Growth.

Jagemann, H. (2003). Sports and the environment: Ways towards achieving the sustainable development of sport. Conference by the 4th Pierre de Coubertin School Forum Arenzano (MUVITA).

Jurowski, C., Uysal, M., \& Williams, D. R. (1997). A theoretical analysis of host community resident reactions to tourism. Journal of Travel Research, 36(2), 3-11.

Kim, J., Gursoy, D., \& Lee, S. (2006). The impact of the 2002 World Cup on South Korea: Comparisons of pre and post games. Tourism Management, 27(1), 86-96. DOI: 10.1016/j.tourman.2004.07.010.

Kline, R. B. (2005). Principles and practice of structural equation modeling (2nd ed.). New York: Guilford Press.

Lankford, S. V., \& Howard, D. R. (1994). Revising TIAS. Annals of Tourism Research, 21(4), 829-831.

Lee, S., Shin, H., \& Park, K. (2009). How public monetary support comes from non-monetary benefits through sporting events. International Journal of Business Research, 9(4), 185-193.

Leed, M., \& Allmen, P. (2005). The economics of sports (2nd ed.). New York: Pearson Addison Wesley.

Madrigal, R. (1993). A tale of tourism in two cities. Annals of Tourism Research, 20(2), 336-353. DOI: 10.1016/01607383(93)90059-C.

Magdalinski, T., \& Nauright, J. (2004). The commercialization of the Olympics. In T. Slack (Eds.), The commercialization of sport (pp. 185-204). London: Routledge.

Mihalik, B. J., \& Cummings, P. (1995). Host perceptions of the 1996 Atlanta Olympics: Support, attendance, benefits, and liabilities. Travel and Tourism Research Association 26th Annual Proceedings, 397-400.

Milnthorp, R. (2002). The economic impact of the 2002 Saskatchewan Winter Games. Retrieved April 12, 2006, from http://www.lin.ca/lin/resource/html/ac700.pdf

Morgan, J. (1997). Glory for sale. Baltimore, MD: Bancroft Press. 
Nielsen. (2010). Top broadcast sports program. Retrieved February 12, 2010, from http://sports.espn.go.com/nfl/ playoffs/2009/news/story?id=4897094

Noll, R. G., \& Zimbalist, A. (1997). Sports, jobs and taxes: The economic impact of sports teams and stadiums. Washington, DC: Brookings Institution Press.

Olds, K. (1998). Urban mega-events, evictions, and housing rights: The Canadian case. Current Issues in Tourism, 1(2), 2-46. DOI: 10.1080/13683509808667831.

Olympics: Vancouver 2010 Olympics committee runs deficit. (2008, October 17). Otago Daily Times. Retrieved February 18, 2010, from http://www.odt.co.nz/27803/ vancouver039s-2010-olympics-committee-runs-deficit.

Perdue, R. R., Long, P.T., \& Kang, Y. S. (1999). Boomtown tourism and resident quality of life: The marketing of gaming to host community residents. Journal of Business Research, 44(3), 165-177. DOI: 10.1016/S01482963(97)00198-7.

Porter, P. K. (1999). Mega-sports events as municipal investments: A critique of impact analysis. In J. Fizel, E. Gustafson, \& L. Hadley, (Eds.), Sports economics: Current research. Westport, CT: Praeger Press.

Preuss, H. (2004). The economics of staging the Olympics. Cheltenham, UK: Edward Elgar.

Preuss, H. (2005). The economic impact of visitors at major multi-sporting events. European Sport Management Quarterly, 5(3), 281-301.

Preuss, H., \& Solberg, H. A. (2006). Attracting major sporting events: The role of local residents. European Sport Management Quarterly, 6(4), 391-411.

Rascher, D. A. (2002, July). Real impact. Sport Travel Magazine, 29-30.

Ritchie, J. (1984). Assessing the impact of hallmark events: Conceptual and research issues. Journal of Travel Research, 23(1), 2-11. DOI: 10.1177/004728758402300101.

Roche, M. (1994). Mega-events and urban policy. Annals of Tourism Research, 21(1), 1-19. DOI: 10.1016/01607383(94)90002-7.

Rosentraub, M. (1994). Sport and downtown development strategy. Journal of Urban Affairs, 16(3), 228-239.

Santo, C. A. (2010). Cities, stadiums, and subsidies: Why cities spend so much on sports. In C. Santos \& G. Mildner (Eds.), Sport and public policy: Social, political, and economic perspectives (pp. 65-96). Champaign, IL: Human Kinetic.

Satorra, A., \& Bentler, P. M. (1994). Corrections to test statistics and standard errors on covariance structure analysis. In A. von Eye \& C.C. Clogg (Eds.), Latent variables analysis (pp. 399-419). Thousand Oaks, CA: Sage.
Seigfried, J., \& Zimbalist, A. (2000). The economics of sports facilities and their communities. Journal of Economic Perspectives, 14(3), 95-114.

Shapcott, M. (1998). Commentary on urban mega-events, evictions and housing rights: The Canadian case by Kris Olds. Current Issues in Tourism, 1(2), 195-196. DOI: 10.1080/13683509808667840.

South Africa 2010 World Cup. (2008). Venues. Retrieved February 16, 2010, from http://www.savenues.com/2010. htm.

Steiner, M., \& Thöni, E. (1999). Sport as a tool for regional development: The case of GRAZ 2002. In C. Jeanrenaud (Ed.), The economic impact of sporting events. Palais Du Peyrou, Switzerland: CH 2000 Neuchatel.

Sweeney, B. (2009, March 20). How the Olympic Games displace millions of city-dwellers. Retrieved February 21, 2010, from http://www.humanrights.dk/News/Archive/ News $+2007 /$ How +the+Olympic +Games+Displace+ Millions+of+City-Dwellers.

Tosun, C. (2002). Host perceptions of impacts: A comparative tourism study. Annals of Tourism Research, 29(1), 231-245. DOI: 10.1016/S0160-7383(01)00039-1.

Turco, D. M. (1995, June). Measuring the economic impact of a sporting event. Paper presented at the 1995 North American Society for Sport Management Annual Conference, New Brunswick, Canada.

Vancouver Olympics: Hottest ticket ever? High prices for hockey final. (2010, February 27). The Associated Press. Retrieved March 1, 2010, from http://www.deseretnews. com/article/700012721/2010-Winter-Olympics-Hottestticket-ever-High-prices-for-hockey-final.html?pg=all.

Viuker, S. (2002). Safe and secure: Security is paramount in the US following the World Trade Center attacks on September 11, 2001. Panstadia International Quarterly Report, 8(3), 16-19.

Whitson, D., \& Macintosh, D. (1996). The global circus: International sport, tourism, and the marketing of cities. Journal of Sport and Social Issues, 20(3), 278-295. DOI: $\underline{10.1177 / 019372396020003004 .}$.

Wikipedi (2010). 2010 FIFA World Cup. Retrieved April 29, 2013, from http://en.wikipedia.org/wiki/2010_FIFA_ World Cup

Winters, D. K. (2004). The economic contribution of the 2004 PGA championship to the State of Wisconsin. Retrieved March 22, 2005, from http://agency.travelwisconsin.com/ Research/PGA impact.phf.

Witt, S. F. (1988). Mega-events and mega-attractions. Tourism Management, 9(1), 76-77. DOI: 10.1016/02615177(88)90063-5. 